\title{
Serological detection of Anaplasma phagocytophilum, Borrelia burgdorferi sensu lato and Ehrlichia canis antibodies and Dirofilaria immitis antigen in a countrywide survey in dogs in Poland
}

\author{
Friederike Krämer • Roland Schaper • Bettina Schunack • Andrzej Polozowski • \\ Jolanta Piekarska • Aleksandra Szwedko • Robert Jodies - Dagmara Kowalska • \\ Dörte Schüpbach • Nikola Pantchev
}

Received: 14 May 2014 / Accepted: 6 June 2014 / Published online: 29 June 2014

(C) The Author(s) 2014. This article is published with open access at Springerlink.com

\begin{abstract}
Canine vector-borne diseases (CVBDs) have increasingly become a focus of attention in the past few years. Nevertheless, in many parts of Europe information on their occurrence is still scarce. In a large study in Poland 3,094 serum samples taken from dogs throughout all 16 Polish provinces were tested using a commercial kit for the detection of circulating antibodies against Anaplasma phagocytophilum, Borrelia burgdorferi sensu lato and Ehrlichia canis and of Dirofilaria immitis antigen. A total of $12.31 \%(381 / 3,094$; $95 \%$ confidence interval [CI]: $11.18-13.52 \%)$ and $3.75 \%$ (116/3,094; $95 \%$ CI: 3.11-4.48 \%) of the dogs were positive
\end{abstract}

\section{F. Krämer}

Institute for Parasitology and Tropical Veterinary Medicine, Faculty of Veterinary Medicine, Freie Universität Berlin, 14163 Berlin, Germany

R. Schaper $(\square) \cdot$ B. Schunack

Bayer Animal Health GmbH, 51373 Leverkusen, Germany

e-mail: Roland.Schaper@bayer.com

A. Połozowski · J. Piekarska

Department of Internal Medicine and Clinic of Horses, Dogs and Cats, Faculty of Veterinary Medicine, Wroclaw University of

Environmental and Life Sciences, 50-366 Wroclaw, Poland

A. Szwedko

PPH Eskulap, 44-105 Gliwice, Poland

R. Jodies

Lekdijk Oost 11, 4112PB Beusichem, The Netherlands

D. Kowalska

Bayer Sp. z o.o., Animal Health Division, 02-326 Warsaw, Poland

D. Schüpbach $\cdot$ N. Pantchev

IDEXX Vet Med Labor GmbH, 71636 Ludwigsburg, Germany for A. phagocytophilum and B. burgdorferi s.l. antibodies, respectively. Furthermore, $0.26 \%$ (8/3,094; $95 \%$ CI: $0.11-$ $0.51 \%$ were positive for $E$. canis antibodies and $0.16 \%$ (5/3,094; 95 \% CI: 0.05-0.38 \%) for D. immitis antigen. The highest percentages of $A$. phagocytophilum-positive dogs were noted in Lesser Poland, Silesia and Łódź Provinces. For B. burgdorferi s.l., the highest prevalence was recorded in Łódź Province. Co-infections with A. phagocytophilum and $B$. burgdorferi s.l. were recorded in $1.71 \%$ of all examined dogs $(53 / 3,094 ; 95 \%$ CI: $1.29-2.23 \%)$. One dog even had a triple infection, testing positive for $E$. canis too. Both A. phagocytophilum and B. burgdorferi s.l. have previously been reported in Poland and were confirmed in the present study by positive samples from all 16 provinces. Concerning E. canis and D. immitis travel history or importation cannot be excluded as factors which may have determined the occurrence of these pathogens in the relevant animals. Practitioners in Poland should be aware of the above mentioned CVBDs and of prophylactic measures to protect dogs and their owners.

Keywords Dog - Canine vector-borne diseases (CVBDs) . $\mathrm{SNAP}^{\circledR} 4 \mathrm{Dx}^{\circledR} \cdot$ Prevalence $\cdot$ Distribution $\cdot$ Poland

\section{Introduction}

Canine vector-borne diseases (CVBDs) have increasingly become a focus of interest in recent years. Long-term climate change on the one hand, and biotic factors - such as an increase in reservoir abundance, changing habitat structure, socio-political changes and, especially for dogs, increasing 
travel and dog import for welfare reasons - on the other hand are discussed in this context as parameters for the expansion of vectors and pathogens into formerly unaffected areas. Two of these canine vector-borne pathogens, Anaplasma phagocytophilum and Borrelia burgdorferi sensu lato, have now been reported in dogs in nearly all European countries. In some countries, the pathogens have only been reported in the vector, e.g., A. phagocytophilum in Ixodes ricinus ticks in Finland (unpublished data by E. Hasu cited in Heikkilä et al. 2010), Estonia (Katargina et al. 2012) and Lithuania (Paulauskas et al. 2012), or in animals other than dogs, e.g., in a cat in Finland (Heikkilä et al. 2010), but data on canine prevalence of A. phagocytophilum have yet to be published. From the Baltic States plus Belarus, for example, a canine study with confirmed occurrence of A. phagocytophilum could be found only for Latvia (Bērziña and Matīse 2013). Other studies screened only small canine populations in a restricted focus.

The highest number of human cases of borreliosis in Poland in 2011 was registered in Podlaskie Province with 75.5 per 100,000 people (Paradowska-Stankiewicz and Chrześcijańska 2013). Most cases of borreliosis in Poland originally occurred in this north-eastern region, but the disease is no longer solely a problem in this part of the country (Paradowska-Stankiewicz and Chrześcijańska 2013). Other studies on ticks and forest workers in the north-western part of the country revealed prevalences between $7.4 \%$ (Skotarczak et al. 2002) and $16.7 \%$ (Skotarczak et al. 2003) in the tick population and $61 \%$ in forest workers (Niścigorska et al. 2003). Seropositivity was also recorded in dogs in the north-western part of Poland (Skotarczak and Wodecka 2003, 2005). The main vector in the area for the pathogen B. burgdorferi s.l. is I. ricinus, which is generally distributed throughout the country.

The pathogen A. phagocytophilum is reported to occur in its vector I. ricinus in numerous studies in Poland. The prevalence in ticks has been reported across the country (from the north-west (Rymaszewska 2005) to the south-east (Cisak et al. 2005)), ranging from $2.9 \%$ in the central region (Warsaw) (Zygner et al. 2008) to $76.7 \%$ in the south (Lesser Poland) (Asman et al. 2013). In man (mainly forest workers as an especially tick-exposed group within the population), antibodies against $A$. phagocytophilum have also been detected, e.g., in $17.7 \%$ in north-eastern Poland (Roztocze National Park in Lublin) (Cisak et al. 2005) and $19.8 \%$ in the Lublin region (Zwoliński et al. 2004). Finally, dogs have been screened in a few studies, with $2 / 192 \operatorname{dogs}$ being seropositive for A. phagocytophilum in north-western Poland (Skotarczak et al. 2004), $14 \%$ of dogs suspected of having Lyme disease being positive for A. phagocytophilum in a study from Szczecin University (Rymaszewska and Adamska 2011), and 1/79 dogs being positive in a group of apparently healthy sled dogs
(Welc-Falecciak et al. 2009). In addition to the occurrence of the pathogen in dogs, it is also reported in diverse forms of wild life in Poland (e.g., roe deer (Welc-Falęciak et al. 2013); wild boars (Michalik et al. 2012); wild cervids (Hapunik et al. 2011)). Even though this aspect is not examined very often within the canine population, there is a clear risk of infection by frequently reported A. phagocytophilum-positive I. ricinus ticks in Poland.

Autochthonous cases of Ehrlichia canis have so far not been reported in dogs in Poland, and for Dirofilaria immitis only one questionable autochthonous case in Poland without molecular confirmation was described (Światalska and Demiaszkiewicz 2012).

The vector for E. canis is Rhipicephalus sanguineus (Groves et al. 1975; Lewis et al. 1977), which in Europe mainly occurs in places with a Mediterranean climate. For Poland, only two citations of $R$. sanguineus occurrence could be found. One on a mass infestation in an apartment in Warsaw in the 1970s (Szymański 1979) and one on a dog in Warsaw, which might be identical with the publication of the mass infestation in the 1970s, as it is only mentioned in a review by Nowak-Chmura and Siuda (2012) without concrete citation. As Poland is not endemic for $R$. sanguineus, it can be suggested that E. canis infection is not autochthonously occurring in Poland, but is associated with import of dogs or a travel history. Exceptionally, imported ticks may establish populations within all-year temperate homes and subsequently lead to an "autochthonous" infection, as suggested for Germany (Dongus et al. 1996).

Apart from the D. immitis case mentioned above, Dirofilaria repens has so far been detected only in dogs in central Poland (Demiaszkiewicz et al. 2009) and in dogs imported from Poland (Pantchev et al. 2011). Typical endemic areas for D. immitis are found in the Mediterranean region extending up to the Alps. As far as the countries bordering on Poland are concerned, individual cases have been detected in Slovakia (Iglódyová et al. 2012). Nevertheless, evaluating the temperature records, spanning a 29year period (1971-2000), along with the model of Fortin and Slocombe (1981) modified by Lok and Knight (1998), for eastern Europe, a threshold value of 130 cumulative Dirofilaria developing units (DDU) reached in 30 consecutive days, being sufficient to facilitate extrinsic incubation of Dirofilaria, were also recorded for Poland between June and August and to a very reduced amount as well in September (Genchi et al. 2011).

The aim of the study described here was to collect current data on the occurrence and distribution of four major canine vector-borne pathogens via a large nationwide survey of the canine population in Poland. A further aim was to characterise in more detail mixed infections with the various pathogens and areas of high prevalence. 


\section{Material and methods}

\section{General}

Serum samples from 3,094 dogs were analysed in the study. The samples were taken by local veterinarians in 54 participating veterinary practices distributed throughout all 16 Polish provinces. The practices were participating in a research project which formed part of the "European Project for Anaplasma and Borrelia Prevalence in Dogs". The samples were submitted to a diagnostic laboratory for analysis. The origin of the dogs was determined using the postcode supplied with the sample.

Clinical samples, study period, study area

The serum was collected from clinically healthy dogs with a tick history visiting veterinary practices in all 16 Polish provinces. The samples were collected between March and October 2011 .

\section{Laboratory tests, data calculation and visualisation}

The samples were picked up from veterinary clinics by $\mathrm{PPH}$ Eskulap, Gliwice, and then submitted to a private veterinary diagnostic laboratory (IDEXX Vet Med Lab, Ludwigsburg, Germany) for testing of different CVBDs. Serological testing was performed using a rapid assay test system (SNAP ${ }^{\circledR}$ 4Dx ${ }^{\circledR}$, IDEXX Laboratories, Inc., Westbrook, ME, USA) following the manufacturer's instructions for use. SNAP ${ }^{\circledR}$ $4 \mathrm{Dx}^{\circledR}$ (Fig. 1) is a rapid assay test system based on enzyme immunoassay technique. The test has been validated for dogs (Chandrashekar et al. 2010) and is officially registered for use in dogs in Germany by the Friedrich Loeffler Institute (FLI). A test unit consists of a coated membrane matrix with five spots in the reaction area (result window). Three spots are impregnated respectively with a specific peptide antigen of A. phagocytophilum (a synthetic peptide from the major surface protein (p44/MSP2)), B. burgdorferi s.l. (C6 peptide) and
E. canis (peptides from p30 and p30-1 outer membrane proteins). The D. immitis analyte is derived from antibodies specific to heartworm antigens, which are primarily produced by adult females (Weil 1987). The fifth spot serves as a positive control. A two-chamber system contains wash solution and substrate solution, which flow across the coated membrane upon activation of the test (Pantchev et al. 2009a). The sensitivity of the performed test ranges according to the manufacturer from $99.1 \%$ for $A$. phagocytophilum and $98.8 \%$ for $B$. burgdorferi s.1. to $96.2 \%$ for $E$. canis and $99.2 \%$ for $D$. immitis, with a specificity for all four pathogens of $100 \%$ according to Chandrashekar and colleagues (2010). Antibodies against Anaplasma platys in experimentally infected dogs have cross-reacted with the A. phagocytophilum analyte, and the $E$. canis analyte may cross-react with antiEhrlichia chaffeensis antibodies (Chandrashekar et al. 2010). Nevertheless, one natural $A$. platys infection in a dog yielded a negative result in this test (Dyachenko et al. 2012). Crossreactivity of the $D$. immitis analyte in similar commercially available antigen tests with Angiostrongylus vasorum-positive dogs has since been described (Schnyder and Deplazes 2012) and will be discussed later in this publication.

There are a number of different genospecies concerning B. burgdorferi s.l. There are at least three species in Europe that are pathogenic for humans: B. burgdorferi sensu stricto, B. garinii and B. afzelii. The C6 peptide is antigenically conserved among them and may be used to serodiagnose borreliosis universally (Liang et al. 2000). Detection of antibodies against $\mathrm{C} 6$ peptide in dogs by means of commercially available tests does not interact with Borrelia vaccination (O'Connor et al. 2004), succeeds from days 21 to 35 postinfection onwards (Wagner et al. 2012), and persists in untreated dogs for at least 12 months (Levy et al. 2008).

The collected data were analysed by a geographic information system (GIS) using the programme RegioGraph 10 (GfK GeoMarketing, Bruchsal, Germany) to visualise the regional distribution of collected and analysed serum samples and antibody- and/or antigen-positive samples for the different pathogens on administrative maps. Using the three digits as
Fig. 1 Canine $\operatorname{SNAP}^{\circledR} 4 \mathrm{Dx}{ }^{\circledR}$ test device. Schematic illustration (left) and photograph of a test device demonstrated with a canine serum sample positive for Borrelia and Anaplasma antibodies (right)

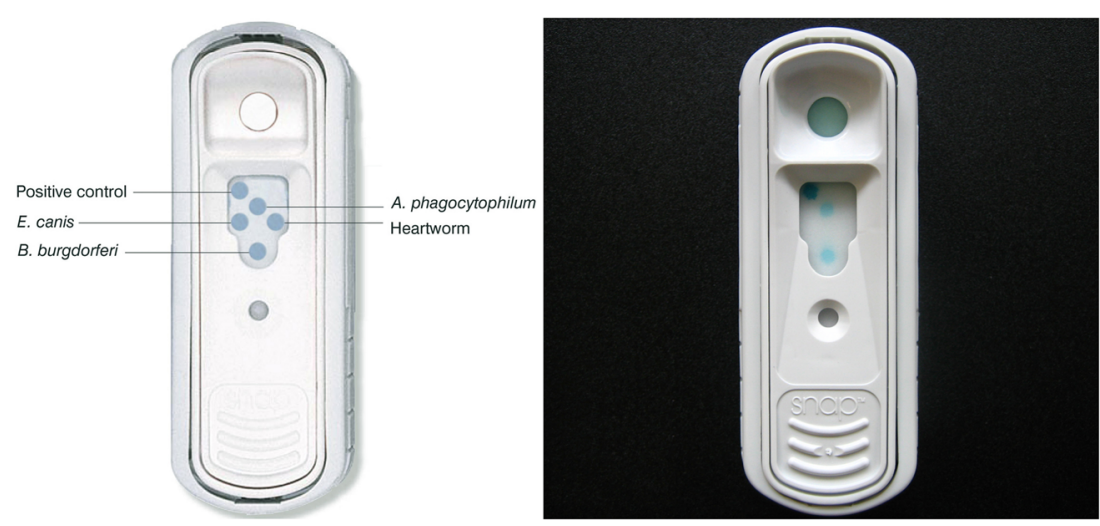


points of reference, the locations of positive samples were displayed on maps with administrative and postcode boundaries.

The descriptive analysis was performed with the help of the validated statistical programme TESTIMATE Version 6.5 from IDV Data Analysis and Study Planning. The presence of antibodies (for A. phagocytophilum, B. burgdorferi s.l. and $E$. canis) or antigen (for $D$. immitis) for every variable was dichotomised into negative (=no presence) and positive (=presence) to calculate the prevalence and the $95 \%$ confidence interval (CI). Additionally, differences from the overall sum for each of the 16 provinces were calculated using the Fligner-Wolfe test (many-to-many test, alpha $=0.05$ ) for A. phagocytophilum, B. burgdorferi s.l. and co-infection with A. phagocytophilum and B. burgdorferi s.l.

\section{Results}

The seropositivity of all tested samples is summarised in Table 1. The overall prevalence of $A$. phagocytophilum and B. burgdorferi s.l. in dogs was $12.31 \%(n=381 ; 95 \%$ CI: $11.18-13.52 \%)$ and $3.75 \%(n=116 ; 95 \%$ CI: $3.11-4.48 \%)$, respectively. The overall prevalence based on the test results for E. canis and D. immitis in dogs was $0.26 \%(n=8 ; 95 \% \mathrm{CI}$ : $0.11-0.51 \%)$ and $0.16 \%(n=5$; $95 \%$ CI: $0.05-0.38 \%)$, respectively.

The results of the $D$. immitis test component of this study need to be discussed differentially. Simultaneous use of highly specific diagnostic methods to differentiate "true" canine heartworm (D. immitis) and "French" heartworm (A. vasorum, a potentially fatal canine nematode that also lives as an adult in the pulmonary arteries) is recommended within overlapping endemic areas, as some commercially available heartworm antigen tests show cross-reactivity with $A$. vasorum (Schnyder and Deplazes 2012). Nowadays, a revised version

Table 1 Results of dog serum samples from Poland $(n=3,094)$ tested for the presence of specific antibodies against Anaplasma phagocytophilum (Ap), Borrelia burgdorferi s.l. (Bb) and Ehrlichia canis (Ec) and of circulating antigen of Dirofilaria immitis (Di)

\begin{tabular}{llll}
\hline Causative organism & $\begin{array}{l}\text { Antibody } \\
\text { (Ap, Bb, Ec) } \\
\text { or antigen (Di) } \\
\text { positive dogs/all } \\
\text { tested dogs }\end{array}$ & Percentage & $\begin{array}{l}95 \% \text { Confidence } \\
\text { interval }\end{array}$ \\
\hline $\begin{array}{c}\text { Anaplasma } \\
\text { phagocytophilum }\end{array}$ & $381 / 3,094$ & $12.31 \%$ & $11.18-13.52 \%$ \\
$\begin{array}{c}\text { Borrelia burgdorferi } \\
\text { s.l. }\end{array}$ & $116 / 3,094$ & $3.75 \%$ & $3.11-4.48 \%$ \\
$\begin{array}{c}\text { Ehrlichia canis } \\
\text { Dirofilaria immitis }\end{array}$ & $8 / 3,094$ & $0.26 \%$ & $0.11-0.51 \%$ \\
\hline
\end{tabular}

of the test system used in this study, SNAP ${ }^{\circledR} 4 \mathrm{Dx}^{\circledR}$ Plus (IDEXX Laboratories, Inc., Westbrook, ME, USA), which does not show any cross-reactivity between $D$. immitis and A. vasorum (Schnyder and Deplazes 2012), and a specific rapid A. vasorum device (Schnyder et al. 2014) are available, but they were not on the market when testing was performed for the present study. Nevertheless, it was possible to follow the above recommendation of simultaneously using highly specific diagnostic methods as the dog population in the study reported here was partially identical with that in a study that examined dogs for the presence of $A$. vasorum antibodies and antigen in Poland (Schnyder et al. 2013). The results of the two studies were compared.

Looking at the five $D$. immitis-positive dogs in this study, a positive $A$. vasorum antigen sandwich ELISA (Schnyder et al. 2011) and A. vasorum antibody sandwich ELISA (Schucan et al. 2012) were reported for one dog from Masovia Province, pointing to potential cross-reactivity between $D$. immitis and A. vasorum. No further information for this dog was available, in particular regarding possible travel to D. immitis-endemic areas. If this dog needed to be considered in terms of a potential cross-reaction with $A$. vasorum, which would be the case if it had no history of travelling abroad, the prevalence of $D$. immitis would have to be corrected to $0.13 \%(4 / 3094$; $95 \%$ CI: 0.04-0.33\%). The other four dogs (from WarmiaMasuria, Opole, Greater Poland and Pomerania Provinces) showed an optical density in the $A$. vasorum antigen sandwich ELISA well below the cut-off within the tested population of Polish dogs (Schnyder et al. 2013) and were thus classified as A. vasorum-negative in the corresponding study. A negative A. vasorum antibody ELISA for these dogs in Schnyder and colleagues (2013) confirms an A. vasorum-negative status and thus a true $D$. immitis-positive result in the performed $\mathrm{SNAP}^{\circledR}$ $4 \mathrm{Dx}{ }^{\circledR}$ test.

The locations of the positive samples (as coloured spots) and the sampling area (in dark grey) on the administrative maps are shown in Figs. 2, 3 and 4. Furthermore, the number of positive samples per province is shown in Table 2 .

Co-infections with A. phagocytophilum and B. burgdorferi s.l. were observed in $1.71 \%(n=53 ; 95 \%$ CI: $1.29-2.23 \%)$ of the tested dogs. One dog proved to have a triple infection with A. phagocytophilum, B. burgdorferi s.l. and E. canis. The proportion of single, double and triple infections in the sum of all positive samples is listed in Table 3 .

A travel history or importation cannot be excluded for dogs positive for E. canis and D. immitis. No co-infections with $D$. immitis were recorded.

The epizootiological situation with respect to infections with A. phagocytophilum and B. burgdorferi s.l. in dogs varies greatly between individual provinces. The highest percentages of dogs (more than $20 \%$ ) infected with $A$. phagocytophilum were noted in Lesser Poland, Silesia and Łódź Provinces, and the lowest percentages (below $5 \%$ ) in Masovia, Subcarpathia 


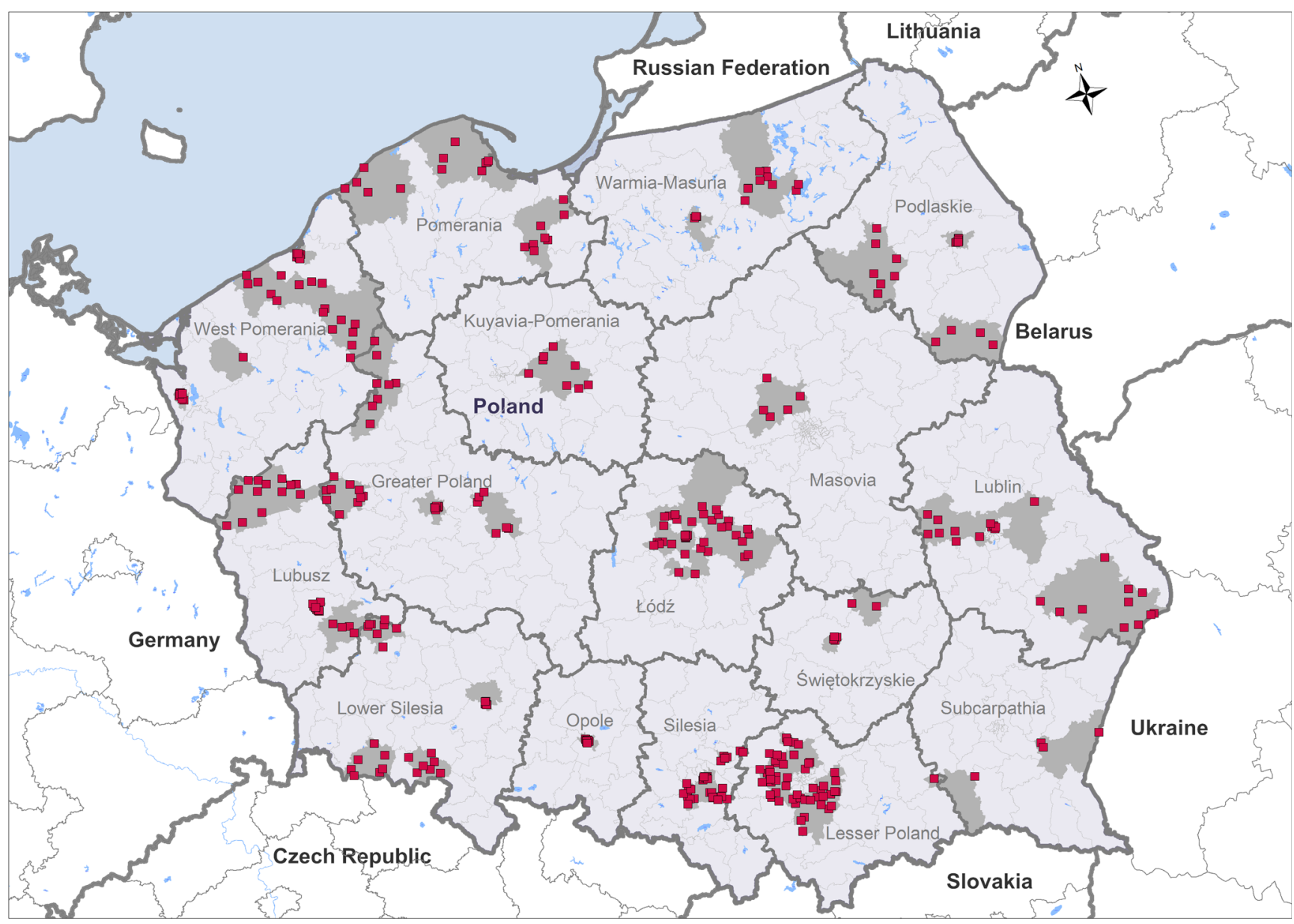

Fig. 2 Occurrence of Anaplasma phagocytophilum-positive dogs detected by $\mathrm{SNAP}^{\circledR} 4 \mathrm{Dx}^{\circledR}$ in a population of 3,094 from Poland. Dark grey areas represent the origin of the tested dog sera. The origins of dogs

and Świętokrzyskie Provinces (see also Table 2). Lesser Poland, Silesia and Łódź Provinces have a significantly (in a descriptive manner) higher prevalence rate than the overall with respect to A. phagocytophilum, while Masovia, Subcarpathia, Świętokrzyskie and Lublin Provinces have a significantly lower prevalence rate than the overall with respect to A. phagocytophilum. The highest prevalence of infection with $B$. burgdorferi s.l. (>10 \%) was noted in dogs from Łódź Province, and the lowest prevalence $(<1 \%)$ was found, just as for A. phagocytophilum, in Masovia Province. These differences in prevalence from the overall were significant in terms of a higher prevalence rate than the overall in Łódź Province and a lower prevalence rate than the overall in Masovia Province for B. burgdorferi s.l. Most cases of co-infection with $A$. phagocytophilum and B. burgdorferi s.l. were observed in Łódź Province (8.49\%), while in Masovia, Subcarpathia and Podlaskie Provinces no such cases were found (see also Table 2). The higher prevalence rate than the overall in Łódź Province is significant for coinfection with $A$. phagocytophilum and B. burgdorferi s.l. The few dogs positive for $E$. canis and D. immitis were positive for circulating A. phagocytophilum antibodies $(n=381)$ are shown in red

distributed throughout the country and no clear regional focus was found.

\section{Discussion}

The main vector of $A$. phagocytophilum and B. burgdorferi s.l. in Poland is the castor bean tick, I. ricinus. It is distributed throughout Poland, so that there is a clear potential for transmission of these two pathogens all over the country. Furthermore, both pathogens occur in dogs, can cause clinical disease in dogs, although for Borrelia so far only pathogenicity of the genospecies B. burgdorferi s.s. has been proven for dogs (reviewed by Krupka and Straubinger 2010), and both also have a zoonotic character. In several studies, mainly concentrating on man and the vector tick, the prevalence of both pathogens has been confirmed in Poland.

Most human cases of borreliosis were originally recorded in the north-eastern part of the country, but there have since also been reports of the pathogen from the north-western region in ticks (Skotarczak et al. 2002, 2003; Skotarczak 


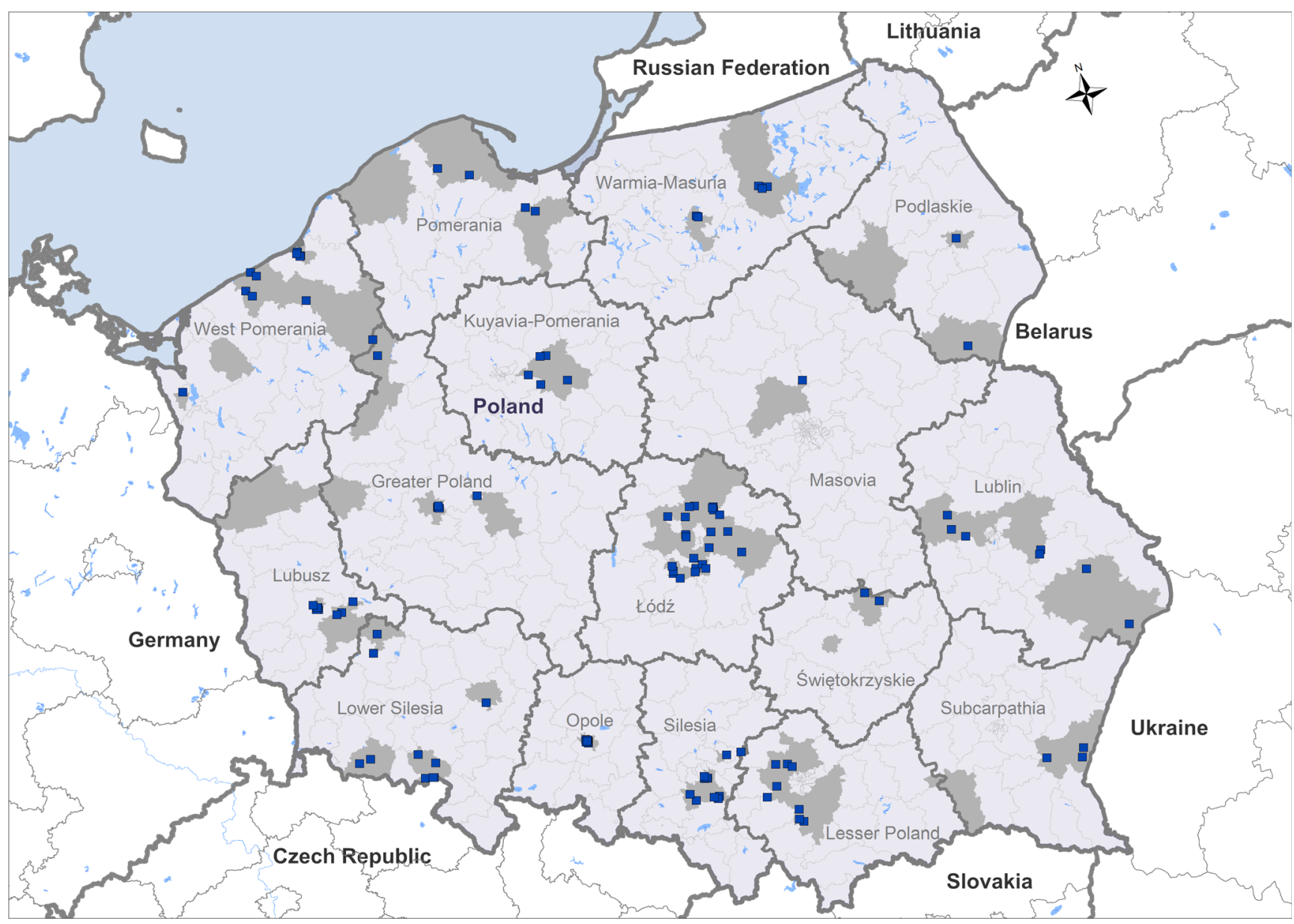

Fig. 3 Occurrence of Borrelia burgdorferi s.1. -positive dogs detected by SNAP ${ }^{\circledR} 4 \mathrm{Dx}{ }^{\circledR}$ in a population of 3,094 from Poland. Dark grey areas represent the origin of the tested dog sera. The origins of dogs positive for circulating B. burgdorferi s.l. antibodies $(n=116)$ are shown in blue

2000; Wodecka and Skotarczak 2000) and of pathogen DNA also in dogs (Skotarczak and Wodecka 2003, 2005). One study from Poland furthermore confirmed the role of the genospecies B. burgdorferi s.s. in canine borreliosis (Wodecka et al. 2009). Vector ticks carrying A. phagocytophilum have been recorded across the country (e.g., from southern (Lesser Poland) (Asman et al. 2013) to central (Warsaw) (Zygner et al. 2008) and northern Poland (Pomerania) (Stańczak et al. 2004)). Dogs mainly from the northwestern region have been reported to be A. phagocytophilumpositive (Skotarczak et al. 2004; Rymaszewska and Adamska 2011), even though Skotarczak and colleagues (2004) presumed that the low prevalence data (PCR-based method) recorded in dogs in that area might indicate that the domestic dog is not a reservoir for Anaplasma in the tested region. Nevertheless, in a large German canine seroprevalence study by Krupka and colleagues (2007), some of the highest prevalences for A. phagocytophilum in dogs were detected in the German postcode regions 0 and 1 $(23.1 \%$ and $25.8 \%)$, representing the German districts bordering Poland and the Czech Republic, and thus may also mirror a focus of $A$. phagocytophilum in dogs in that region covering north-west Poland and north-east Germany. Based on the data for ticks, a more nationwide exposure seems to occur for A. phagocytophilum, in contrast to an apparently more northerly distribution of the borreliosis pathogen.

The prevalence data from the present study could not confirm a more northerly occurrence of dogs positive for B. burgdorferi s.l., but showed by far the highest prevalence in Łódź Province (11.3\%), followed by Opole, KuyaviaPomerania, Silesia and Lower Silesia Provinces, nearly all located in the south-west of Poland (apart from KuyaviaPomerania). A nationwide occurrence of $A$. phagocytophilum in the tested dog population was confirmed, with the lowest prevalences in the north, north-east, central-east and southeast (Pomerania, Warmia-Masuria, Podlaskie, Masovia, Lublin, Świętokrzyskie and Subcarpathia Provinces), regions which in part make up the areas which originally had the highest occurrence of borreliosis. The highest prevalences were recorded in the central and southern regions.

Regarding E. canis and D. immitis seropositivity, the few dogs with a positive reaction $(n=13$, or 12 after one potentially D. immitis/A. vasorum cross-reacting dog had been 


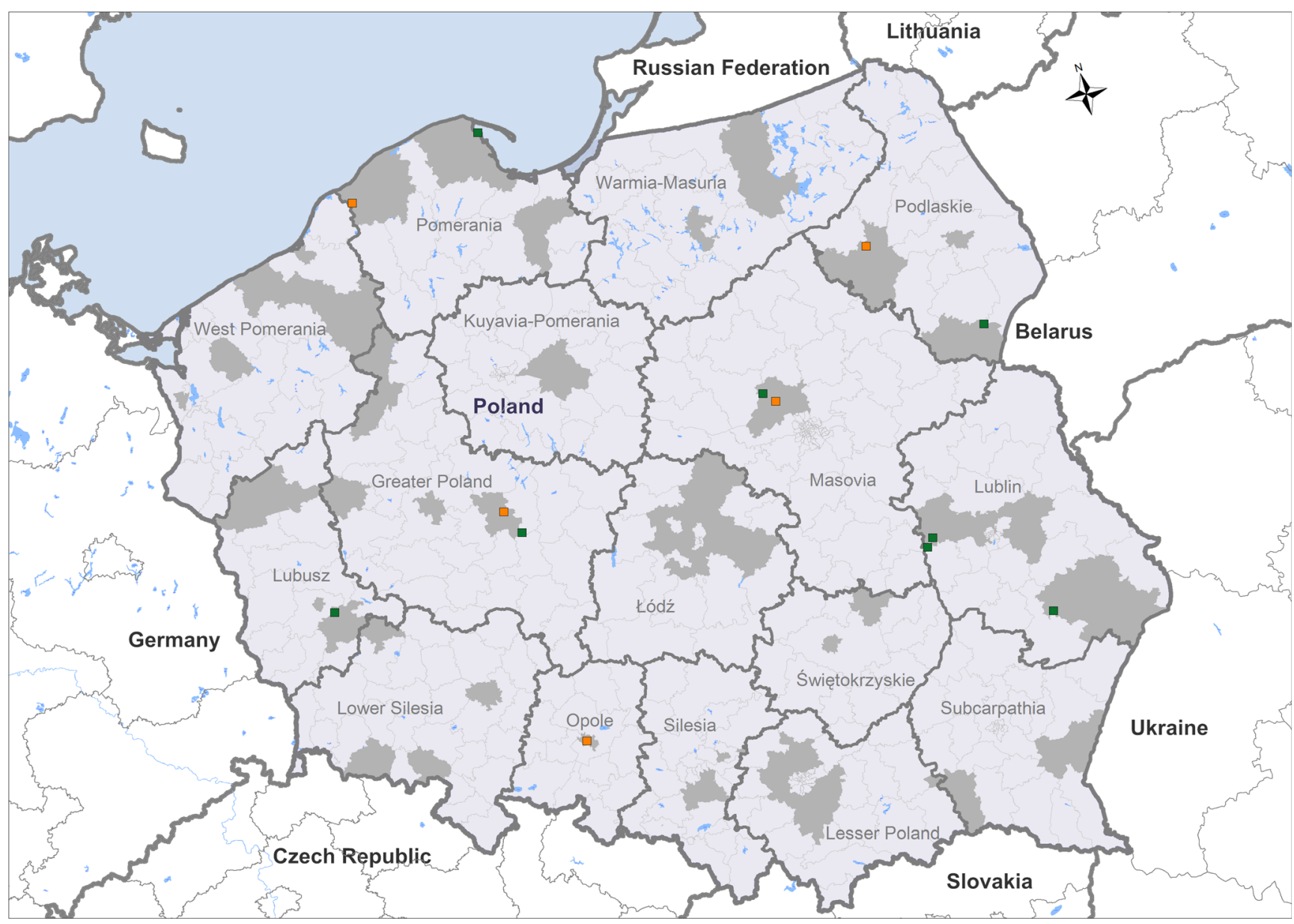

Fig. 4 Occurrence of Ehrlichia canis- and Dirofilaria immitis-positive dogs detected by $\mathrm{SNAP}^{\circledR} 4 \mathrm{Dx}^{\circledR}$ in a population of 3,094 from Poland. Dark grey areas represent the origin of the tested dog sera. The origins of dogs positive for circulating E. canis antibodies $(n=8)$ and D. immitis antigen $(n=5)$ are shown in green and orange, respectively discounted) are distributed throughout the country, so that no clear focus can be described. The fact that so far E. canis has not been reported autochthonously in dogs in Poland, $D$. immitis has only been published with one questionable autochthonous case in Poland without molecular confirmation (Światalska and Demiaszkiewicz 2012), the dogs in the study that were positive for $D$. immitis did not show any co-infection with local agents such as Borrelia/Anaplasma, and finally that no clear regional focus could be identified, raises the question of these dogs' travel history and recent import status. Unfortunately no data were available on these aspects.

The cross-reactivity of the $D$. immitis component of some commercially available tests in $A$. vasorum-positive dogs has been documented (Schnyder and Deplazes 2012). This could have been a reason for the occurrence of $D$. immitis-positive samples in Poland, which has otherwise been negative for heartworm to date. And indeed, clarification of the results by using data available from another study, using partially the same dog population and testing for A. vasorum by using an antigen and an antibody ELISA (Schnyder et al. 2013), showed that one out of five dogs reacted positively in the
A. vasorum tests, pointing to a potential cross-reaction. Examination for microfilariae would have aided discussion of the A. vasorum cross-reaction, as would the travel history of the dog concerned in areas endemic for $D$. immitis. But no data on these aspects were available. Nevertheless, the prevalence of $0.13 \%$ with 4/3,094 dogs reacting positive for $D$. immitis in the study presented here is comparable to the prevalence obtained in an epidemiologically comparable situation in a large German study, where 4/3,005 dogs were D. immitispositive in the SNAP ${ }^{\circledR} 4 \mathrm{Dx}^{\circledR}$ test (Pantchev et al. (2009b), based on the data of Krupka et al. (2007)). None of the dogs positive for $E$. canis or $D$. immitis had a co-infection with the other pathogen, i.e., D. immitis or E. canis.

The number of co-infections with A. phagocytophilum and $B$. burgdorferi s.l. has been the subject of several studies in both man and ticks. As the castor bean tick is the main vector for both pathogens in Poland, a co-infection could result from a dually infected tick. This dual infection has been reported for I. ricinus in northern Poland, e.g., with a prevalence of $8.3 \%$ of 303 examined adult ticks (Stańczak et al. 2004). However, it could also be the result of a simultaneous or sequential 
Table 2 Distribution of Anaplasma phagocytophilum (Ap), Borrelia burgdorferi s.l. (Bb), Ehrlichia canis (Ec) and Dirofilaria immitis (Di) positive samples per province (percentage and total numbers)

\begin{tabular}{|c|c|c|c|c|c|c|}
\hline $\begin{array}{l}\text { Province (number } \\
\text { of veterinary clinics) }\end{array}$ & $\begin{array}{l}\text { Percentage Ap } \\
\text { positive }(x / y)\end{array}$ & $\begin{array}{l}\text { Percentage } \mathrm{Bb} \\
\text { positive }(x / y)\end{array}$ & $\begin{array}{l}\text { Percentage Ec } \\
\text { positive }(x / y)\end{array}$ & $\begin{array}{l}\text { Percentage Di } \\
\text { positive }(x / y)\end{array}$ & $\begin{array}{l}\text { Percentage Ap + } \\
\text { Bb positive }(x / y)\end{array}$ & $\begin{array}{l}\text { Percentage } \mathrm{Ap}+ \\
\mathrm{Bb}+\text { Ec positive } \\
(x / y)\end{array}$ \\
\hline Greater Poland (5) & $12.72 \%(43 / 338)$ & $2.66 \%(9 / 338)$ & $0.30 \%(1 / 338)$ & $0.30 \%(1 / 338)$ & $0.89 \%(3 / 338)$ & \\
\hline $\begin{array}{l}\text { Kuyavia-Pomerania } \\
\text { (1) }\end{array}$ & $10.26 \%(8 / 78)$ & $6.41 \%(5 / 78)$ & & & $1.28 \% \mathrm{c}(1 / 78)$ & \\
\hline Lesser Poland (4) & $25.24 \%(53 / 210)$ & $3.81 \%(8 / 210)$ & & & $2.86 \%(6 / 210)$ & \\
\hline Łódź (4) & $20.28 \%(43 / 212)$ & $11.32 \%(24 / 212)$ & & & $8.49 \%(18 / 212)$ & \\
\hline Lower Silesia (3) & $13.39 \%(15 / 112)$ & $5.36 \%(6 / 112)$ & & & $1.79 \%(2 / 112)$ & \\
\hline Lublin (5) & $7.50 \%(24 / 320)$ & $2.19 \%(7 / 320)$ & $0.94 \%(3 / 320)$ & & $0.94 \%(3 / 320)$ & \\
\hline Lubusz (3) & $16.49 \%(32 / 194)$ & $4.64 \%(9 / 194)$ & $0.52 \%(1 / 194)$ & & $1.55 \%(3 / 194)$ & $0.52 \%(1 / 194)$ \\
\hline Masovia (2) & $3.21 \%(5 / 156)$ & $0.64 \%(1 / 156)$ & $0.64 \%(1 / 156)$ & $\begin{array}{l}0.64 \%(1 / 156) / 0.0 \% \\
(0 / 156)^{\mathrm{a}}\end{array}$ & & \\
\hline Opole (1) & $15.00 \%(18 / 120)$ & $6.67 \%(8 / 120)$ & & $0.83 \%(1 / 120)$ & $1.67 \%(2 / 120)$ & \\
\hline Podlaskie (2) & $9.68 \%(12 / 124)$ & $1.61 \%(2 / 124)$ & $0.81 \%(1 / 124)$ & & & \\
\hline Pomerania (6) & $8.23 \%(20 / 243)$ & $1.65 \%(4 / 243)$ & $0.41 \%(1 / 243)$ & $0.41 \%(1 / 243)$ & $0.82 \%(2 / 243)$ & \\
\hline Silesia (3) & $20.90 \%(42 / 201)$ & $5.97 \%(12 / 201)$ & & & $3.48 \%(7 / 201)$ & \\
\hline Subcarpathia (2) & $4.27 \%(5 / 117)$ & $2.56 \%(3 / 117)$ & & & & \\
\hline Świętokrzyskie (2) & $4.80 \%(6 / 125)$ & $1.60 \%(2 / 125)$ & & & $0.80 \%(1 / 125)$ & \\
\hline Warmia-Masuria (5) & $8.73 \%(20 / 229)$ & $2.62 \%(6 / 229)$ & & $0.44 \%(1 / 229)$ & $0.87 \%(2 / 229)$ & \\
\hline West Pomerania (6) & $11.11 \%(35 / 315)$ & $3.17 \%(10 / 315)$ & & & $0.95 \%(3 / 315)$ & \\
\hline Total (54) & $12.31 \%(381 / 3,094)$ & $3.75 \%(116 / 3,094)$ & $0.26 \%(8 / 3,094)$ & $\begin{array}{l}0.16 \%(5 / 3,094) / 0.13 \% \\
\quad(4 / 3,094)^{\mathrm{a}}\end{array}$ & $1.71 \%(53 / 3,094)$ & $0.03 \%(1 / 3,094)$ \\
\hline
\end{tabular}

$x$ samples positive for a specific pathogen, $y$ total number of samples tested per province

${ }^{a}$ Corrected data after discounting one potential A. vasorum cross-reacting dog in Masovia Province

infection by singly infected ticks. In man, the concurrence of A. phagocytophilum and B. burgdorferi was detected in $3.2 \%$ in north-eastern Poland (Grzeszczuk et al. 2004) and in $4.5 \%$ (15/334) (Zwoliński et al. 2004) and $17.5 \%(11 / 63)$ (Tomasiewicz et al. 2004), both in mid-eastern Poland. One of the main concerns in co-infection is the possibility that the clinical appearance in the patient may be altered, thus potentially making diagnosis more difficult and leading to a more serious disease outcome (Krupka et al. 2007). Furthermore, one pathogen might pave the way for another. In one study, for example, seroreactivity to both A. phagocytophilum and $B$. burgdorferi was detected more frequently in suspected clinical cases in dogs than seroreactivity to either organism alone (Beall et al. 2008). This again should be borne in mind by veterinarians across the country, as exposure to both pathogens seems possible.
The fact that both are zoonotic pathogens indicates the need for greater involvement on the part of the public health authorities.

There are two limitations to this serological survey. First, the dogs' history of travel abroad and their import status were not recorded, so that, for the E. canis- and D. immitis-positive dogs in particular, an autochthonous character cannot be confirmed for Poland. Dogs testing positive in a specific area may have been exposed elsewhere. Second, a positive antibody test is not necessarily equivalent to the existence of the pathogen in the canine or vector population of a particular geographic region; it is only evidence of prior exposure to the corresponding pathogen at some point and some location in the dog's history. With respect to the latter limitation, a more differentiated view needs to be taken of the detection of antibodies against $\mathrm{C} 6$ peptide of $B$. burgdorferi s.l.: The $\mathrm{SNAP}^{\circledR} 4 \mathrm{Dx}^{\circledR}$

Table 3 Proportion of single, double and triple infections in positive samples $(n=456)$

\begin{tabular}{|c|c|c|c|c|c|c|}
\hline & Ap (alone) & $\mathrm{Bb}$ (alone) & Ec (alone) & Di & $\mathrm{Ap}+\mathrm{Bb}$ & $\mathrm{Ap}+\mathrm{Bb}+\mathrm{Ec}$ \\
\hline Positive samples & 328 & 63 & 7 & 5 & 52 & 1 \\
\hline $\begin{array}{l}\text { Percentage } \\
\quad(95 \% \mathrm{CI})\end{array}$ & $\begin{array}{l}71.93 \% \\
\quad(67.56-76.01 \%)\end{array}$ & $\begin{array}{l}13.82 \% \\
\quad(10.78-17.33 \%)\end{array}$ & $\begin{array}{l}1.54 \% \\
\quad(0.62-3.14 \%)\end{array}$ & $\begin{array}{l}1.10 \% \\
\quad(0.36-2.54 \%)\end{array}$ & $\begin{array}{l}11.40 \% \\
\quad(8.63-14.68 \%)\end{array}$ & $\begin{array}{l}0.22 \% \\
\quad(0.01-1.22 \%)\end{array}$ \\
\hline
\end{tabular}

Ap Anaplasma phagocytophilum, Bb Borrelia burgdorferi s.1., Di Dirofilaria immitis, Ec Ehrlichia canis, CI confidence interval 
test detected infection with Borrelia at the earliest on day 35 or day 49 post-infection, depending on the dog (Wagner et al. 2012). On the other hand, antibodies to $\mathrm{C} 6$ have been detected in the late stages of infection ( $>12$ months) with a C6 detecting device (Wagner et al. 2012; Levy et al. 2008), and have been found to decrease significantly after specific treatment, so that at least for Borrelia the detection of C6 peptide might represent a more or less robust marker of infection.

Generally, the large number of dogs included and the fact that two of the pathogens, A. phagocytophilum and $B$. burgdorferi s.l., have also been reported in vector ticks, man or wild life in Poland several times support the conclusion that veterinarians should be aware of infection with these two pathogens potentially in all Polish provinces. Veterinarians should include these two diseases in their differential diagnosis and recommend the use of repellents along with prophylactic measures to prevent disease transmission by arthropod vectors.

In conclusion, this study represents a nationwide overview of the occurrence of important canine, but also zoonotic, pathogens in a large canine population in Poland. Dogs seropositive for A. phagocytophilum (12.31\% prevalence) and B. burgdorferi s.1. (3.75\% prevalence) were detected in all 16 Polish provinces, even though the prevalence varied between the different provinces and a slightly more central/southern/mid-western focus was recorded. Nevertheless, veterinarians throughout the country should be aware that these two major canine vector-borne pathogens may occur in their practice area and exposure of their canine clients is possible.

E. canis and D. immitis were much less prevalent: $0.26 \%$ (E. canis) and $0.16 \%$ (D. immitis). As the travel history and import status of the positive dogs were not available, an autochthonous character of the latter two pathogens cannot be confirmed.

Co-infections with $A$. phagocytophilum and B. burgdorferi s.l. were recorded in $1.71 \%$ of all examined dogs, and one dog was even infected with a third pathogen, E. canis.

Acknowledgements The study was funded by Bayer Animal Health $\mathrm{GmbH}$, Germany. Friederike Krämer is funded in a Bayer project at the Freie Universität Berlin. The authors are indebted to the veterinarians participating in this study.

Ethical standards All investigations comply with the current laws of the countries in which they were performed.

Conflict interests The authors declare that they have no competing interests.

Open Access This article is distributed under the terms of the Creative Commons Attribution License which permits any use, distribution, and reproduction in any medium, provided the original author(s) and the source are credited.

\section{References}

Asman M, Nowak M, Cuber P, Strzelczyk J, Szilman E, Szilman P, Trapp G, Siuda K, Solarz K, Wiczkowski A (2013) The risk of exposure to Anaplasma phagocytophilum, Borrelia burgdorferi sensu lato, Babesia sp. and co-infections in Ixodes ricinus ticks on the territory of Niepołomice forest (southern Poland). Ann Parasitol 59:13-19

Beall MJ, Chandrashekar R, Eberts MD, Cyr KE, Diniz PP, Mainville C, Hegarty BC, Crawford JM, Breitschwerdt EB (2008) Serological and molecular prevalence of Borrelia burgdorferi, Anaplasma phagocytophilum, and Ehrlichia species in dogs from Minnesota. Vector Borne Zoonotic Dis 8:455-464

Bērziña I, Matīse I (2013) Association between the use of the acaricides, household type, tick bite and seropositivity against Anaplasma phagocytophilum and Borrelia burgdorferi sensu lato in clinically healthy dogs in Latvia. Environ Exp Biol 11:47-51

Chandrashekar R, Mainville CA, Beall MJ, O'Connor T, Eberts MD, Alleman AR, Gaunt SD, Breitschwerdt EB (2010) Performance of a commercially available in-clinic ELISA for the detection of antibodies against Anaplasma phagocytophilum, Ehrlichia canis, and Borrelia burgdorferi and Dirofilaria immitis antigen in dogs. Am J Vet Res 71:1443-1450

Cisak E, Chmielewska-Badora J, Zwoliński J, Wójcik-Fatla A, Polak J, Dutkiewicz J (2005) Risk of tick-borne bacterial diseases among workers of Roztocze National Park (south-eastern Poland). Ann Agric Environ Med 12:127-132

Demiaszkiewicz AW, Polańczyk G, Pyziel AM, Kuligowska I, Lachowicz J (2009) [The first foci of dirofilariosis of dogs evoked by Dirofilaria repens Railliet et Henry, 1911 in central Poland.] (in Polish). Wiad Parazytol 55:367-370

Dongus H, Zahler M, Gothe R (1996) [The brown dog tick, Rhipicephalus sanguineus (Ixodidae), in Germany: an epidemiologic study and control measures.] (in German). Berl Munch Tierarztl Wochenschr 109:245-248

Dyachenko V, Pantchev N, Balzer HJ, Meyersen A, Straubinger RK (2012) First case of Anaplasma platys infection in a dog from Croatia. Parasit Vectors 5:49

Fortin JF, Slocombe JOD (1981) Temperature requirements for the development of Dirofilaria immitis in Aedes triseriatus and Ae. vexans. Mosq News 41:625-633

Genchi C, Mortarino M, Rinaldi L, Cringoli G, Traldi G, Genchi M (2011) Changing climate and changing vector-borne disease distribution: the example of Dirofilaria in Europe. Vet Parasitol 176:295299

Groves MG, Dennis GL, Amyx HL, Huxsoll DL (1975) Transmission of Ehrlichia canis to dogs by ticks (Rhipicephalus sanguineus). Am J Vet Res 36:937-940

Grzeszczuk A, Puzanowska B, Miegoć H, Prokopowicz D (2004) Incidence and prevalence of infection with Anaplasma phagocytophilum. Prospective study in healthy individuals exposed to ticks. Ann Agric Environ Med 11:155-157

Hapunik J, Víchová B, Karbowiak G, Wita I, Bogdaszewski M, Pet'ko B (2011) Wild and farm breeding cervids infections with Anaplasma phagocytophilum. Ann Agric Environ Med 18:73-77

Heikkilä HM, Bondarenko A, Mihalkov A, Pfister K, Spillmann T (2010) Anaplasma phagocytophilum infection in a domestic cat in Finland: case report. Acta Vet Scand 52:62

Iglódyová A, Miterpáková M, Hurníková Z, Antolová D, Dubinský P, Letková V (2012) Canine dirofilariosis under specific environmental conditions of the Eastern Slovak Lowland. Ann Agric Environ Med 19:57-60

Katargina O, Geller J, Alekseev A, Dubinina H, Efremova G, Mishaeva N, Vasilenko V, Kuznetsova T, Järvekülg L, Vene S, Lundkvist A, Golovljova I (2012) Identification of Anaplasma phagocytophilum 
in tick populations in Estonia, the European part of Russia and Belarus. Clin Microbiol Infect 18:40-46

Krupka I, Straubinger RK (2010) Lyme borreliosis in dogs and cats: background, diagnosis, treatment and prevention of infections with Borrelia burgdorferi sensu stricto. Vet Clin North Am Small Anim Pract 40:1103-1119

Krupka I, Pantchev N, Lorentzen L, Weise M, Straubinger RK (2007) [Tick-transmitted bacterial infections in dogs: Seroprevalences of Anaplasma phagocytophilum, Borrelia burgdorferi sensu lato and Ehrlichia canis in Germany.] (in German). Prakt Tierarzt 88:776-788

Levy SA, O'Connor TP, Hanscom JL, Shields P, Lorentzen L, Dimarco AA (2008) Quantitative measurement of C6 antibody following antibiotic treatment of Borrelia burgdorferi antibody-positive nonclinical dogs. Clin Vaccine Immunol 15:115-119

Lewis GE Jr, Ristic M, Smith RD, Lincoln T, Stephenson EH (1977) The brown dog tick Rhipicephalus sanguineus and the dog as experimental hosts of Ehrlichia canis. Am J Vet Res 38:1953-1955

Liang FT, Aberer E, Cinco M, Gern L, Hu CM, Lobet YN, Ruscio M, Voet PE Jr, Weynants VE, Philipp MT (2000) Antigenic conservation of an immunodominant invariable region of the VlsE lipoprotein among European pathogenic genospecies of Borrelia burgdorferi SL. J Infect Dis 182:1455-1462

Lok JB, Knight DH (1998) Laboratory verification of a seasonal heartworm transmission model. In: Seward RL, Knight DH (eds) Proceedings of the recent advances in heartworm disease Symposium '98. American Heartworm Society, Tampa, FL, USA, 1-3 May, 1998, pp 15-20

Michalik J, Stańczak J, Cieniuch S, Racewicz M, Sikora B, Dabert M (2012) Wild boars as hosts of human-pathogenic Anaplasma phagocytophilum variants. Emerg Infect Dis 18:998-1001

Niścigorska J, Skotarczak B, Wodecka B (2003) Borrelia burgdorferi infection among forestry workers - assessed with an immunoenzymatic method (ELISA), PCR and correlated with the clinical state of the patients. Ann Agric Environ Med 10:15-19

Nowak-Chmura M, Siuda K (2012) Ticks of Poland. Review of contemporary issues and latest research. Ann Parasitol 58:125-155

O'Connor TP, Esty KJ, Hanscom JL, Shields P, Philipp MT (2004) Dogs vaccinated with common Lyme disease vaccines do not respond to IR6, the conserved immunodominant region of the VlsE surface protein of Borrelia burgdorferi. Clin Diagn Lab Immunol 11:458-462

Pantchev N, Schaper R, Limousin S, Norden N, Weise M, Lorentzen L (2009a) Occurrence of Dirofilaria immitis and tick-borne infections caused by Anaplasma phagocytophilum, Borrelia burgdorferi sensu lato and Ehrlichia canis in domestic dogs in France: results of a countrywide serologic survey. Parasitol Res 105(Suppl):S101-S113

Pantchev N, Norden N, Lorentzen L, Rossi M, Rossi M, Brand B, Dyachenko V (2009b) Current surveys on the prevalence and distribution of Dirofilaria spp. in dogs in Germany. Parasitol Res 105(Suppl):S63-S74

Pantchev N, Etzold M, Daugschies A, Dyachenko V (2011) Diagnosis of imported canine filarial infections in Germany 2008-2010. Parasitol Res 109(Suppl):S61-S76

Paradowska-Stankiewicz I, Chrześcijańska I (2013) Lyme disease in Poland in 2011. Przegl Epidemiol 67(255-7):359-361

Paulauskas A, Radzijevskaja J, Rosef O (2012) Molecular detection and characterization of Anaplasma phagocytophilum strains. Comp Immunol Microbiol Infect Dis 35:187-195

Rymaszewska A (2005) Identification of Anaplasma phagocytophilum on the basis of a fragment of the 16S rDNA gene. Folia Biol (Krakow) 53:199-203

Rymaszewska A, Adamska M (2011) Molecular evidence of vectorborne pathogens coinfecting dogs from Poland. Acta Vet Hung 59: 215-223

Schnyder M, Deplazes P (2012) Cross-reactions of sera from dogs infected with Angiostrongylus vasorum in commercially available Dirofilaria immitis test kits. Parasit Vectors 5:258
Schnyder M, Tanner I, Webster P, Barutzki D, Deplazes P (2011) An ELISA for sensitive and specific detection of circulating antigen of Angiostrongylus vasorum in serum samples of naturally and experimentally infected dogs. Vet Parasitol 179:152-158

Schnyder M, Schaper R, Pantchev N, Kowalska D, Szwedko A, Deplazes P (2013) Serological detection of circulating Angiostrongylus vasorum antigen- and parasite-specific antibodies in dogs from Poland. Parasitol Res 112(Suppl):S109-S117

Schnyder M, Stebler K, Naucke TJ, Lorentz S, Deplazes P (2014) Evaluation of a rapid device for serological in-clinic diagnosis of canine angiostrongylosis. Parasit Vectors 7:72

Schucan A, Schnyder M, Tanner I, Barutzki D, Traversa D, Deplazes P (2012) Detection of specific antibodies in dogs infected with Angiostrongylus vasorum. Vet Parasitol 185:216-224

Skotarczak B (2000) [Borrelia burgdorferi sensu lato occurrence in ticks Ixodes ricinus by polymerase chain reaction (PCR).] (in Polish). Wiad Parazytol 46:93-99

Skotarczak B, Wodecka B (2003) Molecular evidence of the presence of Borrelia burgdorferi sensu lato in blood samples taken from dogs in Poland. Ann Agric Environ Med 10:113-115

Skotarczak B, Wodecka B (2005) Identification of Borrelia burgdorferi genospecies inducing Lyme disease in dogs from Western Poland. Acta Vet Hung 53:13-21

Skotarczak B, Wodecka B, Cichocka A (2002) Coexistence DNA of Borrelia burgdorferi sensu lato and Babesia microti in Ixodes ricinus ticks from north-western Poland. Ann Agric Environ Med 9:25-28

Skotarczak B, Rymaszewska A, Wodecka B, Sawczuk M (2003) Molecular evidence of coinfection of Borrelia burgdorferi sensu lato, human granulocytic ehrlichiosis agent, and Babesia microti in ticks from northwestern Poland. J Parasitol 89:194-196

Skotarczak B, Adamska M, Rymaszewska A, Suproń M, Sawczuk M, Maciejewska A (2004) [Anaplasma phagocytophila and protozoans of Babesia genus in dogs from endemic areas of Lyme disease in north-western Poland.] (in Polish). Wiad Parazytol 50:555-561

Stańczak J, Gabre RM, Kruminis-Łozowska W, Racewicz M, KubicaBiernat B (2004) Ixodes ricinus as a vector of Borrelia burgdorferi sensu lato, Anaplasma phagocytophilum and Babesia microti in urban and suburban forests. Ann Agric Environ Med 11:109-114

Światalska A, Demiaszkiewicz AW (2012) [First autochthonous case of Dirofilaria immitis invasion in dog in Poland.] Źycie Weterynaryjne 87:685-686

Szymański S (1979) [Case of mass infestation with mites of genus Rhipicephalus sanguineus (Latreile, 1806) in a Warsaw apartment.] (in Polish). Wiad Parazytol 25:453-459

Tomasiewicz K, Modrzewska R, Buczek A, Stańczak J, Maciukajć J (2004) The risk of exposure to Anaplasma phagocytophilum infection in Mid-Eastern Poland. Ann Agric Environ Med 11: 261-264

Wagner B, Freer H, Rollins A, Garcia-Tapia D, Erb HN, Earnhart C, Marconi R, Meeus P (2012) Antibodies to Borrelia burgdorferi OspA, OspC, OspF, and C6 antigens as markers for early and late infection in dogs. Clin Vaccine Immunol 19:527-535

Weil GJ (1987) Dirofilaria immitis: identification and partial characterization of parasite antigens in the serum of infected dogs. Exp Parasitol 64:244-251

Welc-Falęciak R, Rodo A, Siński E, Bajer A (2009) Babesia canis and other tick-borne infections in dogs in Central Poland. Vet Parasitol 166:191-198

Welc-Falęciak R, Werszko J, Cydzik K, Bajer A, Michalik J, Behnke JM (2013) Co-infection and genetic diversity of tick-borne pathogens in roe deer from Poland. Vector Borne Zoonotic Dis 13:277-288

Wodecka B, Skotarczak B (2000) [Genetic diversity of Borrelia burgdorferi sensu lato in Ixodes ricinus ticks collected in northwest Poland.] (in Polish). Wiad Parazytol 46:475-485 
Wodecka B, Rymaszewska A, Sawczuk M, Skotarczak B (2009) Detectability of tick-borne agents DNA in the blood of dogs, undergoing treatment for borreliosis. Ann Agric Environ Med 16:9-14

Zwoliński J, Chmielewska-Badora J, Cisak E, Buczek A, Dutkiewicz J (2004) [Prevalence of antibodies to Anaplasma phagocytophilum and Borrelia burgdorferi in forestry workers from the Lublin region.] (in Polish). Wiad Parazytol 50:221-227

Zygner W, Jaros S, Wedrychowicz H (2008) Prevalence of Babesia canis, Borrelia afzelii, and Anaplasma phagocytophilum infection in hard ticks removed from dogs in Warsaw (central Poland). Vet Parasitol 153:139-142 